Article

\title{
Three Women Sharing a Mantle in 6th Century BCE Greek Vase-Painting: Plurality, Unity, Family, and Social Bond
}

\author{
Valérie Toillon \\ Département d'histoire de l'art et d'études cinématographiques, Université de Montréal, Montréal, QC H3T 1J4, \\ Canada; valerie.toillon@umontreal.ca
}

Received: 30 May 2019; Accepted: 22 October 2019; Published: 25 October 2019

\begin{abstract}
The motif of three women sharing the same mantle is pictured on about a dozen vases dating from the first half of the sixth century BCE. Among these vases, the so-called "François Vase" and a dinos signed by Sophilos (now in London, British Museum) are of particular interest. The wedding of Thetis and Peleus is pictured on both vases. This theme is well-adapted to the representation of a procession of deities in which the Charites, Horai, Moirai, and Muses take part. The main feature of these deities is a shared mantle, which covers and assembles them, emphasizing that these deities are plural by definition. The main study on this iconographical theme remains that by Buchholz, who documented most of the depictions of the "shared-mantle" in ancient Greek vase-painting and small terracottas. The shared-mantle motif has been interpreted successively as a reference to the sacred peplos (in relation to the wedding), a simplification from the painter to avoid painting all the mantles, a sign of emotional/sexual union, a religious gesture, and a depiction of choruses. The present study aims to consider in more detail the "shared-mantle" as an iconographic sign that involves the idea of community, shared identity, and emotional bond.
\end{abstract}

Keywords: iconography; Greece; vase-painting; wedding; mantle; chorus

\section{Introduction}

Clothes, shoes, jewelry, and other ornaments are means of non-verbal communication. In fact, in the ancient world, clothing is a way to indicate identity, ethnicity, and social, political, or religious status. In other words, clothing has both sociological and cultural dimension (Gherchanoc and Huet 2007; Lee 2012). This is, therefore, of special interest in the study of ancient Greek iconography, as it is about non-verbal communication. Indeed, iconography considers images as a set of signs that interact with each other just like words in a phrase and phrases in a text. The image draws its significance from the combination and pattern of these signs. Of course, images hold meaning at various levels. First, at the level of the image itself, the different signs that make up the image operate together to create meaning from the picture. Those signs could be objects, figures, plants, animals, and so on, but also gestures and looks. The second level is the object itself; we must not forget that the images are placed on a vase that itself has a specific function related to its form (a crater, an amphora, a hydria, etc.). Therefore, we must ask ourselves what information the vase does, particularly its shape, provide us regarding the meaning of the image. Thirdly, we must take into consideration the larger context of the image such as the findspot (when known), contemporaneous works of art (sculpture, 
terracotta, relief, etc.), texts (literature, epigraphy), as well as the religious and/or political context. All of that, put together, allows one to read the image and determine a meaning. ${ }^{1}$

In vase-painting, clothing can be, like attributes, a way to identify characters, for example with the lion skin of Heracles, the petasos of travelers, the winged shoes of Hermes, or the long dress and ivy crown of Dionysos. Clothing is also a way to differentiate gender, Greeks from non-Greeks, gods from mortals, the citizen from the slave, and so on (Bonfante 1989; Lissarrague 1990; Stewart 1997; Pipili 2000; Cohen 2001; Bodiou et al. 2006). Clothing thus has a strong symbolic power that extends to the act of dressing and undressing (Gherchanoc and Huet 2008). So, what about sharing a garment? What does this image mean?

The standard clothing of women in Archaic and Classical Greece was the $\chi \iota \tau \omega \dot{v}$ (tunic) over

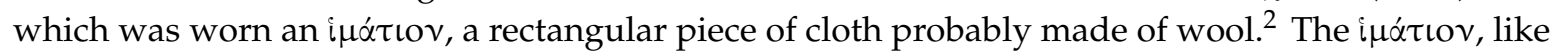
other pieces of cloth, is versatile (Jenkins 1985, p. 117). It could be used as a veil, as well as a cloak or a shawl. This versatile aspect of clothing is notable in visual representations. When a woman is covering her head and face, for example, the i $\mu \alpha$ á ıov is used as a veil (Llewellyn-Jones 2003, pp. 49-56), such as, for example, on an Attic red-figured amphora dated ca. 515 BCE and attributed to the vase-painter Phintias, now in Paris, Louvre Museum, showing "the abduction of Leto by Tityos."3 The goddess is identified by her name $(\lambda \varepsilon \tau o v)$ written beside her. She is brutally seized by the waist by a naked man. The scene takes place under the eyes of Apollo (names inscribed-A $(\pi) \mathrm{o} \lambda \lambda \mathrm{o} v$ ) and Artemis $([\mathrm{A} \rho \tau \varepsilon] \mu \iota \delta \mathrm{o} \varsigma)$. The divine twins are Leto's children and, according to Pherekides (3F56), the killed Tityos, Leto's assailant. The story is also told in Homer's Odyssey (Gantz 1993, pp. 39-40). ${ }^{4}$ Therefore, in the picture, the naked man could be identified as Tityos. Leto lifts part of her himation near her face as a veil. In this context, the veil, a common element of the wedding iconography, should be seen as a sign of Leto's modesty (Oakley and Sinos 1993; Llewellyn-Jones 2003, p. 108). In contrast, when the himation covers the shoulders and the lower body, it functions as a mantle or a shawl, as we see on an Attic lekythos attributed to the Amasis Painter, now in the Metropolitan Museum of Art (ca. 550-530 BCE), where two women participate in a wedding procession. They are covering their shoulders with a himation, using it as a shawl or a mantle. ${ }^{5}$

In vase-painting, figures that share a piece of cloth-either a mantle or a blanket-are not rare, but it is not a common iconographic feature either. Generally, the so-called "shared-mantle" motif presents at least two figures (two men, a man and a woman, or two women), facing each other and wrapped together under a large piece of cloth (Buchholz 1987, pp. 17-33). The motif appears in sixth-century black-figure vase-painting, as well as in early fifth-century red-figure vase-painting with some differences. In red-figure vase-painting, sharing a piece of cloth is less frequent and mostly reserved for couples, whereas in black-figure, the motif is more frequent and rather reserved for female

1 The bibliography on this subject is extensive. Since reconsidering theoretical approaches on ancient Greek iconography is not the subject of this paper, see for recent analysis: (Steiner 2007; Lissarrague 2015; Squire 2015). On context in ancient Greek art: (Rodríguez-Pérez 2017).

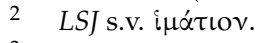

3 Paris, Louvre Museum G 42 (BAPD 200116ARV². 23.1, 1620; Add². 154). On the veil: (Cairns 2002; Llewellyn-Jones 2003, pp. 41-83, 85-120). On Leto's modesty: (Cairns 1996a, 1996b).

4 Hom. Od. 11.576-581.

5 Attic black-figure lekythos, attributed to the Amasis Painter (ca. 550-530 BCE), New York, Metropolitan Museum of Art 56.11.1 (BAPD 350478 Para.66). Also: Attic black-figure amphora (ca. 520 BCE), London, British Museum B171 (BAPD 5725). Obverse: Judgment of Paris: Hera and Aphrodite are wearing embroidered himatia wrapped around their shoulders. 
characters. ${ }^{6}$ The figures are generally depicted walking together or facing each other (standing or sitting), in groups ranging from two up to nine, sharing the same cloak or veil. ${ }^{7}$

The shared-mantle motif is not a new topic and has been studied several times, from Guarducci's article, "Due o più donne sotto un solo manto in una serie di vasi greci arcaici" (Guarducci 1928) to Buchholz's reference study that documented the majority of the depictions of the "shared-mantle" in ancient Greek vase-painting and small terracottas (Buchholz 1987). ${ }^{8}$ Generally, it is suggested that sharing a mantle or blanket (khlaina) is a symbol of marital and sexual union (Scheid and Svenbro 1994, pp. 61-116). Therefore, the "shared-mantle" is often interpreted iconographically as a sign of union, affection, and more specifically, eroticism (Furtwängler 1883, p. 51; Deonna 1914, pp. 52-53; Koch-Harnack 1989; Rabinowitz 2002). For example, a fragment of an Attic red-figure cup, now in Paris, Louvre Museum and dated ca. 525-500 BCE, shows a man and a woman, facing each other, wrapped in the same cloth as a mean for sexual union. ${ }^{9}$ This "emotional interpretation", i.e., the shared-mantle as a sign of union and affection, has not been further studied and scholars have been more interested in exploring a religious meaning in connection with ceremonies implying the offering, transportation, or manipulation of a piece of cloth such as peplophoria, or mystery cults (Guarducci 1928, pp. 58-59; Jucker 1963, p. 56; Fridh-Haneson 1983, pp. 74-82; Buchholz 1987, p. 51; Villanueva Puig 2004). The "shared-mantle", in some cases, has also been interpreted as a way to depict a chorus. This was first suggested by Furtwängler (1883, pl. 51) in his commentary of an Attic black-figured cup found in Argos [cat. 8], on which nine women are assembled under the same mantle on the obverse, and on the reverse, seven women are depicted following the same schema. But the author rapidly dismissed this suggestion, preferring a more practical one, i.e., the "shared-mantle" is a simplification that avoids the repetition of a single motif. The idea of the "shared-mantle" as a depiction of a chorus was presented again by Crowhurst (1963, pp. i-v) with regard to the "François Vase", followed by Calame in his study about the choruses of young girls in archaic Greece (Calame 1977, pp. 81-84). Yet, this idea was not considered in later studies. More recently, Larson interpreted the "shared-mantle" as a specific feature for triads of female divinities such as the Charites or Horai, but she does not take this interpretation further (Larson and Larson 2001, pp. 259-62).

The present study aims to reconsider the early interpretation—too quickly discarded—of the "shared-mantle" as an iconographic sign that involves the idea of community, shared identity, and emotional bond. This motif applies perfectly to female groups of deities such as the Charites, Horai, and Muses, who are defined precisely by their family ties and shared identity. Rather than providing a general interpretation that applies to all the depictions of the "shared-mantle", I will focus on one specific depiction, namely those that show three women walking together as a group and sharing a mantle. This representational type corresponds to Buchholz' "Prozessionsschema" in his study (Buchholz 1987, pp. 26-33). I will then consider the idea that the motif of three women sharing a mantle possibly conveys to its viewers or users the meaning of a chorus of women, as first suggested by Crowhurst and Calame.

6 For example: Attic red-figure cup (ca. 480 BCE), Durham, Private (BAPD 352458; Para. 336), on which a man and a woman are lying on a kline and covered by a mantle. The same idea is on an Attic red-figured cup attributed to the Eucharides Painter (ca. 490 BCE), New-York, Metropolitan Museum of Art 19.192.32 (BAPD 202282; ARV 2 .231.80; Add ${ }^{2} .200$ ). See (Buchholz 1987, pp. 20-47). However, there are some depictions of two men sharing a cloak in sixth-century black-figure vase painting. For example, two young men sharing a cloak: Attic black-figure lekythos (ca. 525-500 BCE), Paris, Louvre Museum F194 (BAPD 10130; Haspels, ABL 65, note 1).

7 Attic black figure pyxis, (ca. 550-540 BCE), Athens, national Museum 500 (BAPD 301468; ABV. 302.2): Three women sharing the same piece of cloth. Attic black-figure lekythos, attributed to the Pharos Painter (ca. 550 BCE), New York, Metropolitan Museum of Art 75.2.10 (BAPD 370003; ABV. 698; Para. 199.1; Haspels, ABL. 194.1, 5, 25, PL.8.1): two women facing each other in one cloak.

8 State of the question: (Villanueva Puig 2004). Studies before 1987: (Buchholz 1987, pp. 17-19).

9 Attic red figure cup (fragment), ca. 525-500 BCE, Paris, Louvre Museum G 99 (BAPD 201652; ARV 2 . 180.1; Add ${ }^{2}$. 186.). 


\section{Results}

As mentioned in the introduction, the present paper is based on the previous study by Buchholz (1987). His study offers a very substantial catalogue of depictions of the shared-mantle in ancient Greek vase-painting and terracottas. In the part of his study dedicated to "Prozessionschema," i.e., two to nine women standing and sharing a cloak, Buchholz categorizes the depictions into three groups according to the number of figures sharing a cloak (Buchholz 1987, pp. 26-33). In other words: Two, three, or more figures assembled by the same piece of cloth $(a, b, c)$. Yet, it is interesting to consider not just the number of figures sharing a mantle, but also how they share it. In other words, are the figures grouped under the same cloak standing together or facing each other? Are they standing one behind the other, the piece of cloth stretched between them? Or are they placed next to each other; the piece of cloth wrapped around them?

To address these questions, the present study aims to focus on the motif of the shared mantle with three standing women placed next to each other, slightly overlapping, and sharing a mantle. We can find this motif on six black-figure craters (Corinthian and Attic) dated ca. 600-570 BCE, one black-figure Chalcidian psykter, and one Corinthian pinax (all of them are already in Buchholz study). To this inventory, I have added two Corinthian black-figure column craters [cat. 4 and 6] and one Eretrian black-figure lidded-amphora [cat. 12] on which the same motif appears. With this group, I include an Attic black-figure kylix found in Argos, on which the motif applies to a larger number of figures (nine and seven women) [cat. 8]. This results in a corpus of 12 objects listed at the end of the paper in the form of a catalogue for the sake of clarity. All the objects are dated between ca. 600 and 540 BCE. To my knowledge, there are no later examples of the motif. The corpus consists mainly of Middle-Corinthian and Attic black-figure craters decorated with procession scenes, on which the shared-mantle motif is clearly recognizable, i.e., three women, standing next to each other with a slight overlap, and sharing a cloak. The earliest of these "shared-mantles" is, to my knowledge, a Corinthian column crater dated ca. 600-590 BCE, preserved in the Louvre Museum, and attributed to the Memnon Painter [cat. 1]. The scene consists of four groups of three women that share the same himation. They are distributed symmetrically on either side of a standing man who is holding a spear. Likewise, on a column crater in Rome, Villa Giulia [cat. 4], groups of women face men riding on a chariot and are arranged following a processional schema. A column crater in Basel [cat. 2] and a fragment in The Hague [cat. 6] show a similar type of scene. Groups of two to three women wrapped in the same mantle are taking part in a procession with men holding spears (Figure 1). These four craters form a first, homogeneous group that shows the "shared-mantle" motif incorporated into a procession with armed men. Is it a military procession, or could it be a procession of armed men participating in larger celebrations such as religious ceremonies? ${ }^{10}$ Unfortunately, the pictures on the vases are not explicit enough to allow for a definitive answer.

On a Corinthian column crater, now in the Vatican Museum [cat. 3] dating from ca. 590-580 BCE, two groups of three women sharing the same mantle flank a couple riding on a chariot. The woman is making the anakalypsis gesture (unveiling) typical of wedding scenes in vase-painting (Figure 2). More generally, the unveiling indicates sexual maturity and/or marital status (Oakley and Sinos 1993, p. 30; Sutton 1981, p. 165). ${ }^{11}$ A similar gesture is found on two fragments of a Corinthian crater [cat. 5], on which a group of three women faces a couple riding on a chariot (Figure 3). On the Eretrian amphora in Athens [cat. 12], three women sharing the same himation are followed by an aulos player, all of whom are walking in front of a couple riding on a chariot. The woman is making the anakalypsis gesture and, facing the chariot, another woman is holding torches. The couple is followed by Dionysos

10 On this point see (Burkert 2011, pp. 144-46 pompè) with bibliography.

11 On the anakalypsis and anakaluptêria see: schol. Eur. Phoenic. 682, attributed to Euphorion of Chalcis (Cusset and Acosta-Hugues 2012; Llewellyn-Jones 2003, pp. 98-104). 
and a goddess. ${ }^{12}$ This seems to be a wedding scene, as Boardman has demonstrated (Boardman 1952, pp. 32-35). Indeed, wedding processions took place at night and a torch bearer is a good way to indicate the nocturnal atmosphere. ${ }^{13}$ In vase-painting, the wedded couple is often guided to their new home by a torch bearer, and on an Attic black-figure lekythos attributed to the Amasis Painter dated ca. 550-530 BCE in the Metropolitan Museum, a woman, perhaps the groom's mother, holds a torch to greet the procession. ${ }^{14}$ The bridal couple is sitting in a cart drawn by two mules. The couple is preceded by a woman holding two torches, one in each hand (Oakley and Sinos 1993, pp. 27-33).

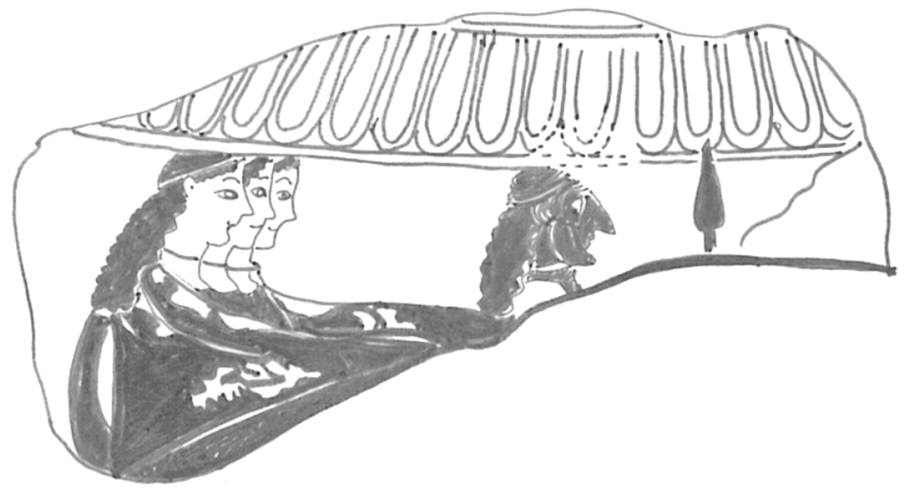

Figure 1. Fragment of a Corinthian column crater. The Hague, Scheurleer Museum inv. 2034. (Drawing by the author).

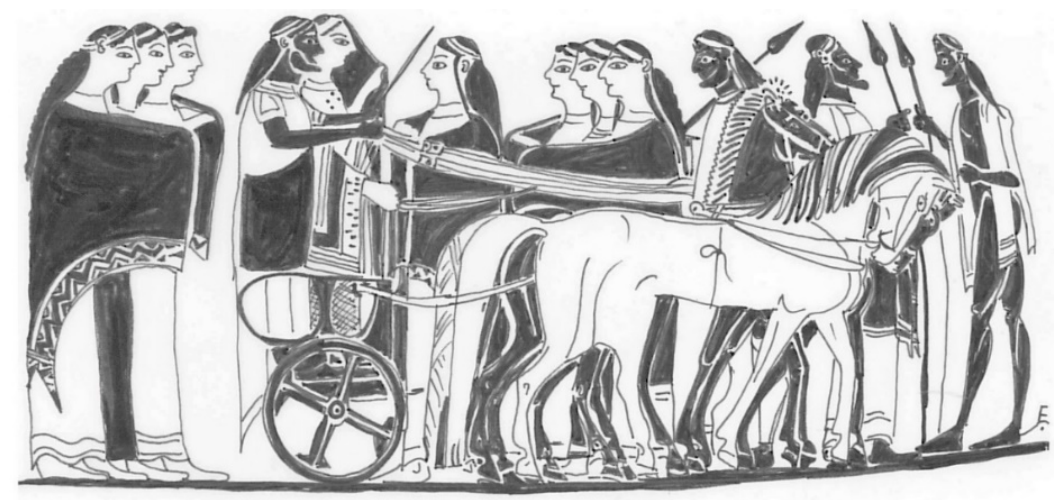

Figure 2. Corinthian Column Crater. Vatican, Museo Gregoriano Etrusco 126. Drawing by the author.

12 The goddess is holding a flower, an attribute related to Aphrodite and her seductive powers over humans and animals (for example: Homeric Hymn to Aphrodite, 1-6; 68-74; Hom. Il.14.214-219, etc.). For example, a "Nikosthenic" amphora in the Six technique dated ca. 520-510 BCE, in Paris, Louvre Museum F 114, shows a naked girl holding a flower near her face. The picture is like a nude study, carefully drawn, emphasizing the beauty and erotic appeal of the girl (BAPD 302837; ABV.226; $A d d^{2}$. 58). See also: Attic black-figure amphora fragment (ca. $\left.520 \mathrm{BCE}\right)$, Boston, Museum of Fine Arts 03.849 (BAPD 591): A woman (maybe Aphrodite) holding a flower. Attic white-ground lekythos attributed to Douris (ca. 500-490 BCE), Cleveland Museum of Art 1966.114 (BAPD 275976; Para.376.266 Bis; $A d d^{2}$. 241): Atalanta running between erotes with wreath and flowering branches. Attic red-figure cup (ca. 490 BCE), New York Metropolitan Museum of Arts 07.286.5 (BAPD 209975; $A R V^{2}$.806.): Aphrodite (named) holding a flower. On Aphrodite: (Pironti 2013, pp. 153-208).

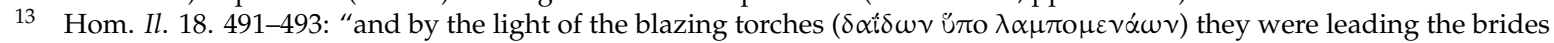
from their rooms through the city, and loud rose the bridal song" (trans. A. T. Murray). See also: Eur. Hel. 722-724; Ion 1475; Med. 1026-1027; Phoen. 344-345; Tro. 308-324; Diod. 13.84.2-3; Tac. Ann. 15.37; (Oakley and Sinos 1993, pp. 26-28).

14 New York, Metropolitan Museum of Art 56.11.1 (see note 5). Also: Attic black-figure hydria (ca. 550-530 BCE), Paris, Louvre Museum F 42 (BAPD 301479; ABV.304.1; $A d d^{2}$.79): A wedded couple in a chariot, facing them, a woman holding torches. Attic black-figure hydria (ca. $530 \mathrm{BCE}$ ), Fiesole, A. Costantini (BAPD 6811): Wedded couple in a chariot, facing them a woman with torches. Very similar: Attic black figure neck-amphora (ca. 520-500 BCE), Paris, Louvre Museum F 232 (BAPD 320230; ABV. 281.10). 


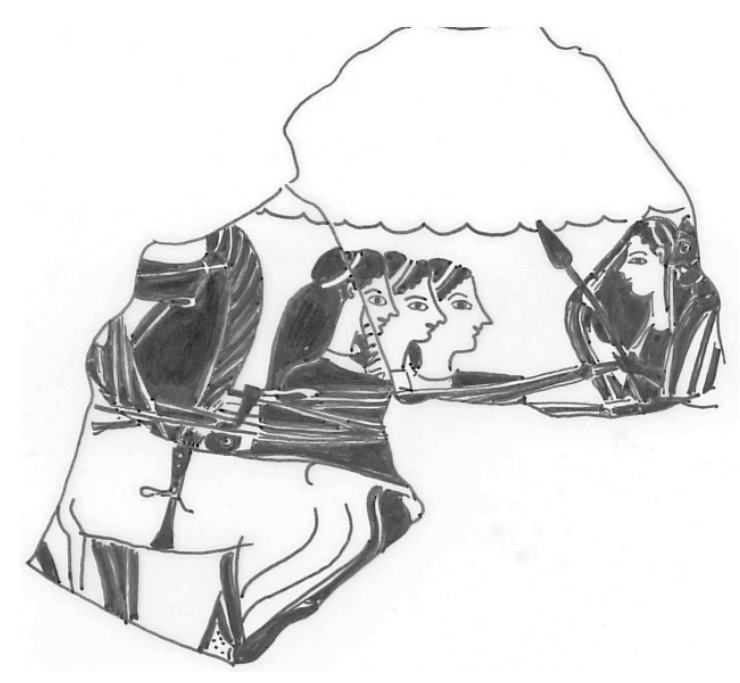

Figure 3. Fragment(s) of a Corinthian column crater. The Hague, Scheurleer Museum inv. 2032-2033. (with a fragment in Copenhagen, National Museum 12.350.). Drawing by the author.

The best-known depictions of the "shared-mantle" motif are the Attic dinos signed by Sophilos and now in the British Museum [cat.9], dated ca. 580 BCE, and the so-called "François Vase" in Florence, signed by Kleitias (painter) and Ergotimos (potter) [cat. 10] and dated ca. 570 BCE. On both Sophilos's dinos and the "François Vase", the shared mantle is specific to a group of deities clearly identified by their names written above or beside their image. Like our second group of Corinthian craters [cat. 3, 5] and the Eretrian lidded amphora [cat. 12], the pattern is integrated into a wedding scene, here specifically that of Thetis and Peleus. On Sophilos's dinos, the Muses, grouped in three and five, share the same mantle. The Charites, the Moirai, Eilithyia, and Hebe also share a mantle, as well as a group of three goddesses whose names have disappeared, perhaps the Horai. All these groups of goddesses precede a pair of Olympian gods riding on a chariot. The distribution is similar to that found on the "François Vase": The Muses are individually named (grouped by three and four), the Horai (three); Hestia, Chariklo, and Demeter also stand out due to their shared-mantle (Figure 4). Similar to the Sophilos' dinos, these groups of deities punctuate the composition and are placed in front of a pair of Olympian gods riding on a chariot, for example, Zeus and Hera, preceded by Ourania, Kaliope, and the Horai.

At first glance, the presence of the "shared-mantle" motif on the "François Vase" and Sophilos' dinos looks like a "borrowing" from Corinthian iconography, especially because the depiction of three women under the same mantle is, as stressed by Benson, specific to Middle Corinthian vase-painting (Benson 1969, p. 114). On the one hand, Sophilos was a student of the Gorgon Painter, who is considered as the main artist of early Attic black-figured vase-painting. Sophilos is the last of this first generation and his paintings drew much inspiration from Corinthian vase-painting, especially in the use of outline drawing for female characters (dress, faces). The other common point with Corinthian vase-painting is the composition itself, in the alternation of groups on foot and figures in chariots when depicting processions (Boardman 2003, pp. 18-19; Williams 1983, pp. 28, 33). On the other hand, the "François vase," dating ca. 570 BCE, about a decade later than Sophilos's dinos, represents a critical time in the production of Attic vase-painting. It represents the second generation of Attic vase-painters, which links early Attic vase-painting (Gorgon Painter, Sophilos) to vase-painters such as Lydos, the Amasis painter, or Exekias (Boardman 2003, pp. 31-34; Reusser 2013). Kleitias's rendering of the wedding of Thetis and Peleus is similar to Sophilos in many respects, especially when considering his use of the "shared-mantle" motif for some groups of female deities. The motif, which seems well-adapted to processions in Corinthian imagery-weddings, religious celebrations-is transposed into the mythological world. While the women sharing the same mantle remain individually anonymous in Corinthian iconography, Sophilos and Kleitias have chosen to 
name them, therefore refining the meaning of the "shared-mantle" motif. We should note, however, that the four Moirai on the "François Vase" do not share the same garment, but they are nevertheless identified by a single name in the plural indicating that they form a unit (Figure 5). The same applies to the Numphai on Sophilos's dinos, who are depicted next to each other without sharing the same mantle but are identified by the inscription "Nuphai" in the plural. ${ }^{15}$ All representations of these deities-Moirai, Charites, Horai-whether they share the same mantle or not, are depicted in the same way through overlapping on Sophilos's dinos and the "François Vase;" it is the same on the Corinthian craters cited previously [cat. 1, 2, 3, 4, 5,6].
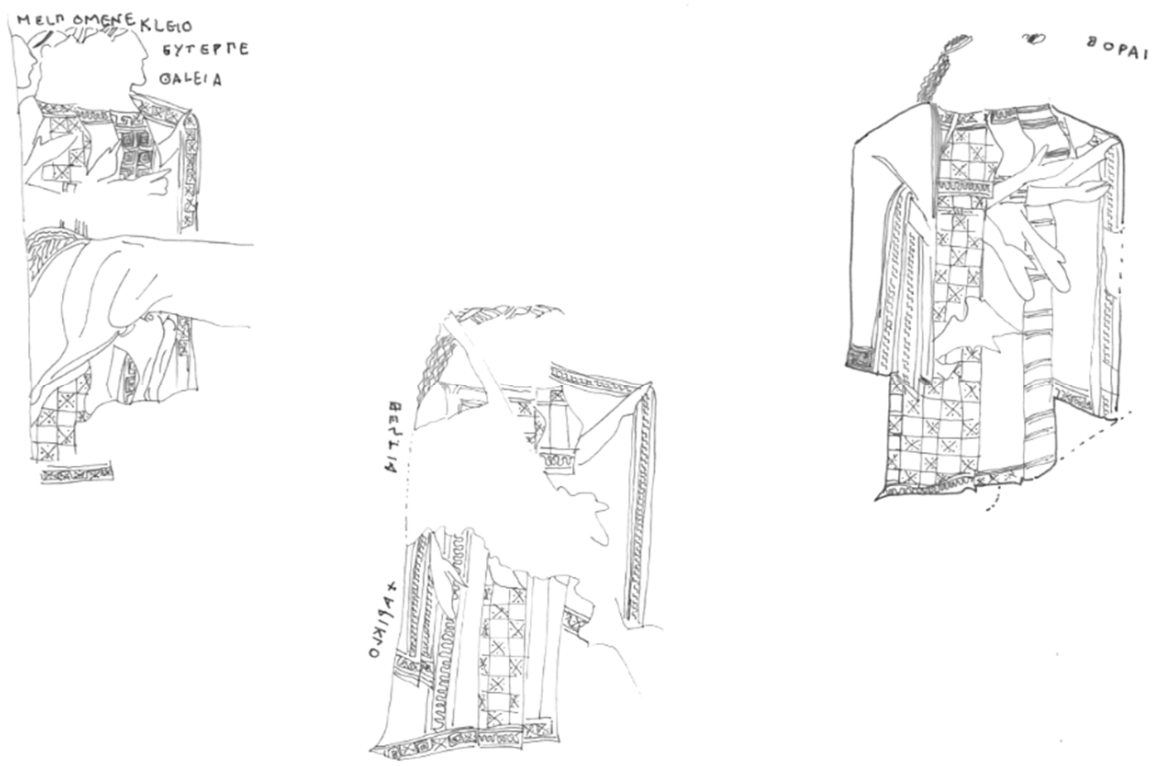

Figure 4. Black-figured volute crater (Attic). Florence, Museo Archeologico inv. 4209. Signed by Kleitias (painter) and Ergotimos (Potter), ca. 570 BCE. (left) The Muses; (center) Hestia, Demeter, Chariklo; (right) the Horai. Drawing by the author.

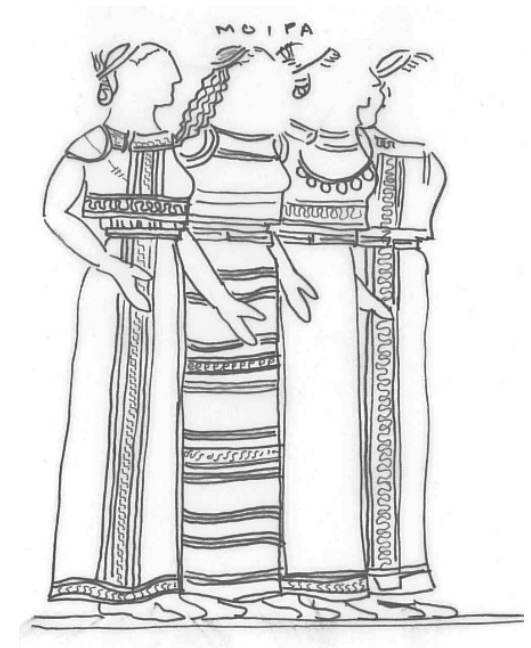

Figure 5. The Moirai. Black-figured volute crater (Attic). Florence Museo Archeologico etrusco inv. 4209. Signed by Kleitias (painter) and Ergotimos (Potter), ca. 570 BCE. Drawing by the author.

15 See also the Dioscuri on an Attic black-figured hydria (ca. 560-540 BCE). Basel, Antikenmuseum BS 1401 (BAPD 4422 ; LIMC III s.v. Dioskouroi 180). As pointed by V. Dasen, the twins are pictured "superimposed with a slight overlap" with "Dioskoro" in the dual written next to them, emphasizing that they are an indivisible entity (Dasen 1997, p. 53). 
Most of the craters (five out of eight) discussed previously have been found in Etruria (especially Caere), whether they are Corinthian or Attic craters. We know that Etruria had an active commercial relationship with Corinth, and then Athens, since the seventh century BCE. The crater was a very popular shape among the Etruscan clientele. However, we do not know for sure what was the precise use of Greek vessels in Etruscan society: Were these vessels used to display wealth and prestige during banquets? Were they used as ceremonial vessels (i.e., not for use, just for display)? As funerary offerings? As wedding gifts? All of the above? In any case, the pictures painted on the craters studied here may have had a special meaning for the Etruscan clientele: the women sharing a mantle are taking part in processions related to special events such as weddings, with the more refined examples transposed into the mythological world (Genière 1988; Boardman 1998, pp. 182-83; Isler-Kerényi 1997, pp. 532-35; Paléothodoros 2002; Reusser 2013). In addition, the Corinthian pinax excavated from the shrine of Pitsa, near Corinth [cat. 7], was probably a votive object. ${ }^{16}$ The context may, therefore, be related to ritual practices. But we cannot say more, since the pinax is very fragmentary and only the three women sharing a cloak can be seen (Orlandos 1935, p. 5; Larson and Larson 2001, Figure 5.18). Finally, the Eretrian black-figure lidded-amphora was used as a funerary urn for a child (Boardman 1952, pp. 32-35). The iconography is mostly nuptial (a wedding scene on the belly, the judgment of Paris on the neck). The vessel conveys an eschatological message connecting wedding and death, a topic often used for youth who died before they were of marriageable age (Kurtz and Boardman 1971). The wedding scene, painted on the belly of the amphora, also has a funerary meaning, especially because of the two Sirens who are flying in front of the chariot (two Sirens are also painted on the obverse of the vase). ${ }^{17}$ We know that Sirens have a mediating role between the world of the living and the world of the dead. They act as guides for the deceased. Likewise, Sirens are also an evocation of the "social self" (fame, knowledge, and intellect) of the deceased who continues to live thanks to the souvenir, especially in the funerary lament such as the threnos (Bettini and Spina 2010, pp. 54-55, 130-34; Johnston 1999, pp. 100-101; Nagy 1999, pp. 171-72; Vermeule 1979). ${ }^{18}$

As mentioned earlier, the whole corpus of vases is somewhat homogenous. The "shared-mantle" appears in a ceremonial context, whether it is weddings or what seems to be religious ceremonies ("armed processions"). This pattern encourages the interpretation of the "shared-mantle" as a specific sign that stresses the idea of unity and shared identity. First, the figures with a "shared-mantle" overlap, a way to indicate group and unity. Moreover, the "shared-mantle" brings out the figures who are equipped with it. The women sharing a mantle appear as a unit. As we will see further below, the "shared-mantle" indicates unity in plurality. Therefore, the figures that are united by the mantle are referring to characters that are defined by their plurality.

\subsection{Plurality and Unity}

\subsubsection{Overlap}

The overlapping of figures is a very common iconographical solution, especially in sixth-century black-figure vase painting. In addition to indicating depth, it is also a way of depicting a group of characters, whether pairs of gods or horses and cattle. In a more general sense, it is a way of representing the unity of an entity made up of several elements (Deonna 1914, pp. 49-50). For example, the three bodies of Geryon are depicted in this manner on an Attic black-figure cup in Rome, Villa Giulia

16 On pinakes: (Karoglou 2010).

17 Boardman (1952) interprets the Sirens as a "good omen" for the wedded.

18 Eur. Hel. 167-178; See also: Attic, black-figure funerary plaque (ca. 625-610 BCE), Boston, Museum of Fine Arts 27.146 (BAPD 3748): Prothesis with a siren under the funerary bed (in connection with Boston, Museum of Fine Arts 27.147: Three women mourning (BAPD 4959); LIMC spp. 1. s.v. seirenes. 
(Figure 6). ${ }^{19}$ The phalanx on the so-called "Chigi Olpe" is also depicted using overlap, as well as a group of warriors on a Corinthian column crater in Basel. ${ }^{20}$ Likewise, overlap is used to represent Geryon's cattle on a Chalcidian amphora in Paris, Cabinet des Médailles. ${ }^{21}$ It is the same for the Boreads and Harpies on a Laconian cup now in Rome, Villa Giulia. ${ }^{22}$ Returning to the "François vase" and Sophilos's dinos, the overlapping of figures mainly applies to deities that share the same prerogatives, identified by their plurality, for example the Muses, the Horai, or the Charites. On a black-figure hydria attributed to the Priam Painter, now in Berlin, a group of four women follows a young kitharode. ${ }^{23}$ The group is accompanied by Dionysos and goes to meet Hermes and a woman, perhaps a goddess (Leto or Artemis). The four women are identified as the Muses for their association with the musician, identified as Apollo because of the cithara, a common attribute of the god. ${ }^{24}$ Furthermore, the Muses are commonly associated with Apollo in Archaic literature, for example in Hesiod's Theogony (94-95): "For it is through the Muses and far-shooting Apollo that there are singers and harpers upon the earth". ${ }^{25}$ A series of Attic black-figure amphorae dating from ca. 520-500 BCE show groups of two overlapping maidens, placed on each side of a young man playing cithara who could be Apollo, as can be seen on an Attic black-figure amphora attributed to the Leagros Group (ca. 510 BCE), now in the British Museum in London. ${ }^{26}$ The young women that accompany the young kitharode are identified as Muses or Nymphs because of their proximity to Apollo, as documented in literary sources and other works of arts, such as the chest of Kypselos (dating ca. 550 BCE), a lost work of art on which Apollo is depicted, according to Pausanias $(5.18,4)$, leading the chorus of the Muses. Likewise, an Attic black-figure amphora in the Museo Civico, Orvieto, attributed to the Euphiletos Painter, shows groups of three and two women, maybe maenads or Nymphs, walking together in a procession. ${ }^{27}$ In each group, the women overlap to form homogeneous groups. The following examples indicate that the

19 Geryon: Hes. Theog. 287-294. See also: Attic black-figure amphora, (ca. 550-530 BCE), London British Museum B157 (BAPD 11916; CVA, London, British Museum 3, III He. 4, Pl. 26. 3A-D; LIMC IVs.v. Eurythion II 15); Attic black-figure amphora (ca. 540 BCE). New York, Metropolitan Museum of Art 56.171.11 (BAPD 301036; ABV. 133.2; Para. 54; CVA, New York, Metropolitan Museum of Art 3, Pl. 15. 1-2.; LIMC IV, s.v. Eurythion II 12; V., s.v. Herakles 2484).

20 Corinthian column crater (ca. 590-570 BCE), Basel, Antikensammlungen BS 451 (CVA, Basel, Antikenmuseum 1, 47-48, Pls. 14. 1-25, 15. 1-3).

21 Chalcidian amphora (ca. 540-530 BCE), Paris, Cabinet des Médaillles 202 (BAPD 909851; CVA, Paris, Bibliothèque Nationale 1, 19-21, pls. 24. 1-4, 25. 1-7); see also: "Pontic" amphora (ca. 550 BCE), Munich Antikensammlung SH837 (BAPD 9034556 ; CVA. Munich, Antikensammlungen ehemals Museum Antiker Keinkunst 17, 23, 24, 25, 26, Beilage 1.1, Pls. 5. 1-2, 6. 1-3.). Apollo's cattle: Caeretan black-figure hydria (ca. 550-520 BCE), Paris, Louvre Museum E702 (BAPD 1007817; CVA Paris, Musée du Louvre 9, III. F.A.9, III. FA.10, Pls. 8.3-4, 10.1-7).

22 Laconian cup attributed to the Boreads Painter (ca. 550 BCE), Rome, Museo Nazionale Etrusco di Villa Giulia (LIMC III s.v. Boreadai $6=$ LIMC IV s.v. Harpyiai 23). See also: Attic plate, black figure, attributed to Lydos (ca. 560 BCE), Oxford (Miss.), Robinson collection (BAPD 310200; ABV. 112.54; Para. 44; Add 2. 31; CVA. Baltimore, Robinson Collection 1, 40, Pl. 19.1. A-B; LIMC III s.v. Boreadai 1); Attic black-figure cup (ca. 560 BCE), Athens, Acropolis Museum 1.1757 (BAPD 32393; LIMC III s.v. Boreadai 2); Attic black-figure column crater, attributed to the Cavalcade Painter (ca. 575 BCE) Thessaloniki, S. Andreadis Coll. (LIMC III s.v. Boreadai 4 = LIMC IV s.v. Harpyiai 21); Laconian cup attributed to the Boreads Painter from the Heraion of Samos (ca. 575-570 BCE). Samos, Vathy Museum K1540 and K 1206 (LIMC IV s.v. Harpyiai 22 = LIMC III s.v. Boreadai 5); Laconian cup attributed to the Boreads Painter (ca. 550-540 BCE), Malibu, J. P. Getty Museum 85.AE.461 (BAPD 1002343; LIMC IV s.v. Harpyiai 24).

23 Attic black-figure hydria attributed to the Priam Painter (ca. 540-530 BCE), Berlin, Antikensammlung F1905 (BAPD 301801 ; $A B V .332 .23$; Para. 146; $\left.A d d^{2} .90\right)$.

24 Hes. Theog. 95; Homeric Hymn to Apollo 131, 182-203. For example, Attic black-figure Amphora (A) attributed to the Priam Painter (ca. 540-530 BCE), Chiusi, Museo Archeologico Nazionale 1794 (BAPD 301779; ABV. 330.1; Para. 146; ARV2. 89): Artemis mounting in her chariot, accompanied by Apollo (named) playing cithara. Attic black-figure amphora (ca. 500-480 BCE), New York, Market, Christie's (BAPD 29): young man playing cithara (Apollo?) between Hermes (caduceus, petasos) and Dionysos (cantharos, vine). See also LIMC II s.v. Apollo 82-238 (esp. Apollo 119, 120, 122), 689-733 (esp. 702, 779b and 780).

25 Also: Homeric Hymn to Apollo 182-203; Homeric hymn to Apollo and the Muses 1-3.

26 Attic black-figure amphora attributed to the Leagros Group (ca. 510-500 BCE), London, British Museum B 261 (BAPD 302171; ABV. 373.176; Para. 163; Add². 99; CVA London, British Museum 4, III. He. 9, Pl. 64.2 A-B; LIMC VI, Pl. 387, s.v. Mousa-Mousai 28b). Also: Attic black-figure amphora attributed to the Leagros group (ca. 510-500 BCE), Agrigento, Museo Archeologico Regionale R 138 (BAPD 15752; CVA Agrigento, Museo Archeologico Nazionale 1, 13, Pls. 22.1-2, 23.1-2, 28.3). See Anne Queyrel commentaries in: LIMC VI s.v. Mousa-Mousai 28a,b, 32, 33, 124, 126, $129 a, 137$.

27 Attic black-figure amphora attributed to the Euphiletos Painter (ca. 520 BCE), Orvieto Museo Civico 273 (BAPD 301730 ; $A B V$. 325). See: (Villanueva Puig 2004). 
overlap is an effective visual way of expressing the unity of a group, especially for deities defined by their plurality.

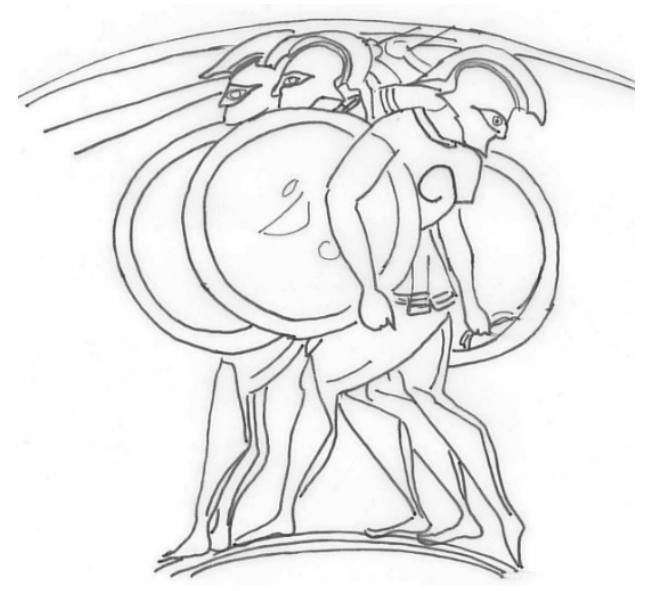

Figure 6. Black-figured cup (ca. 550-530 BCE), Rome, Museo Nazionale di Villa Giulia 1225 (CVA, Rome Museo Nazionale di Villa Giulia 3, III H. E. 18, Pls. 29.2-5, 30.1-2). Drawing by the author.

\subsubsection{Clothes, Groups of Deities}

Clothing has symbolic value that is strongly related to social status and identity. Persons who share the same mantle seem to have a common identity and/or status, especially when these figures are of the same gender and/or have family ties (by blood or marriage), a relationship and identity expressed by the shared clothing. For example, Deianeira and Iole proclaim in Sophocles, Trachiniae (539-540): "And now we are two, a pair waiting under a single bedspread ( $\chi \lambda \alpha i v \alpha)$ for one man's embrace". The statement is about the shared status of two women married to the same man (Heracles), the khlaina being a symbol of marriage (Scheid and Svenbro 1994, pp. 68-82). Likewise, on a series of Etruscan bronze mirrors, the Dioscuri are depicted facing each other and sharing a mantle. ${ }^{28}$ There is little doubt that the shared mantle is a way to highlight both their emotional and genetic bound (Buchholz 1987, p. 34), the Dioscuri being a model for inseparable and complementary brotherhood. Back to the "shared-mantle", the motif combined with the overlapping of figures appears to emphasize the idea of plurality, while, at the same time, transmitting the idea of unity.

The Muses, the Charites, the Horai, and the Morai, who share the same mantle on the "François vase" and Sophilos' dinos, form groups of deities who are considered as a collective before being individuals (Burkert 2011, pp. 240-42). In art, the Charites and the Horai were mostly depicted as triads. $^{29}$ Similarly, it is primarily as a group rather than individuals that they are honored in cult. For example, according to Pausanias, the Horai were represented sitting on a throne in the temple of Hera at Samos. ${ }^{30}$ On the base of Apollo's cult statue in Amyclea (dated ca. 550 BCE), the Muses, the Horai, and the Morai form groups; their names are indicated in the plural (Moirai, Horai, Mousai) but no number is specified. ${ }^{31}$ These groups of deities take part in the apotheosis of Hakynthos and his sister Periboia, as well as in Heracles' deification. On the chest of Kypselos (dated about the middle of the sixth century BCE), the Muses form a group, a chorus, led by Apollo, which is specified by an inscription: "This is Leto's son, prince Apollo, far-shooting; Around him are the Muses (Moũ $\sigma \alpha \iota)$, a graceful choir, whom he is leading". ${ }^{2}$ Likewise, in Thebes there was an altar dedicated to the

28 LIMC III s.v. Dioskouroi 165, 180, 182; Tinas Cliniar 3, 4, 7, 9. See A. Hermary' s commentaries: 567-593.

29 LIMC III sv. Charis, charites; LIMC V s.v. Horai (esp. commentary of V. Machaira: 508-510).

30 Paus. 5.17, 1. See also a limestone carved group (ca. 450 BCE). Paris, Louvre Museum Ca 442. Three deities (maybe Charites) standing next to each other, in a row.

31 Paus. 3.19, 4-5.

32 Paus. 5. 18, 4 (translated by (Jones and Ormerod 1918)). 
Morai, but with no cult statue. ${ }^{33}$ There was a cult to the Charites in Orchomenos, ${ }^{34}$ and a shrine of the Horai in Argos, as well as in Olympia, where there was an altar dedicated to the Horai next to Aphrodite's altar. ${ }^{35}$ In each example, the deities are mentioned by their names in the plural. Moreover, the Muses are mentioned as a group that sings and dances together in the Theogony, before being individually named (line 76 to 79). ${ }^{36}$ Still, in Hesiod Theogony, the Muses are at first called "daughters

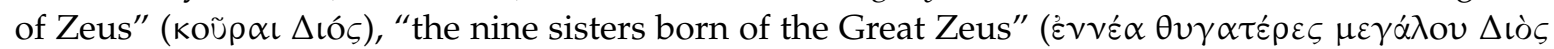
$\left.\varepsilon_{\varepsilon} \gamma \varepsilon \gamma \gamma \alpha \mathcal{L} \tilde{\iota} \iota\right) .{ }^{37}$ As P. Murray stated, the Muses are "a group of sisters sharing a single consciousness each of them implying all the other". They do not have their own personality, they act as a group, and are interchangeable (Murray 2008, pp. 202-03). It is the same for the Horai, the Charites, and the Morai. Before naming them individually, Hesiod considered them as a plurality. ${ }^{38}$ Their individual names specify their respective responsibilities and/or qualities while affirming the broader sphere of action of each triad evoked (Rudhardt 1999, pp. 82-96; Hésiode 2008, pp. xvi, 95-97).

Furthermore, we must pay attention to the word thronos, usually translated as "throne" or "chair". ${ }^{39}$ As Scheid and Svenbro clearly demonstrated, based on a scholion by Kleitarchos, thronos could also, in some contexts, refer to clothing as a synonym for himation, peplos, or khlaina (Scheid and Svenbro 1994, pp. 65-68)..$^{40}$ In Archaic literature, for example, poikilothronos and krusothronos are thus referring to the "gleaming clothes" or the "golden clothes" of goddesses, such as Hera or Aphrodite, rather than to a throne. ${ }^{41}$ In Pindar, these special clothes are an attribute to the Muses and Horai who are "euthronos" ("with beautiful clothes"). ${ }^{42}$ Likewise, the Charites have their "thrônai" in the Olympus, which could as well designate a garment or a throne (Scheid and Svenbro 1994, pp. 86-91). ${ }^{43}$ The beautiful and gleaming clothes of the Muses and Horai act as a sign of their divinity. ${ }^{44}$ Also, the "beautiful clothes" of the Horai, the Muses, or the Charites emphasize that these groups of deities are desirable and characterized by their youth and beauty (Swift 2016, pp. 257-262). Clothing is, then, an important part of the divine appearance. It is well expressed, for example, on the "François vase" where the Muses and Charites are dressed in richly decorated garments with elaborated patterns. In these pictures, the mantle is also a part of that divine costume. Having a mantle shared by several deities highlights their collective divine status.

\subsection{Family Ties and Affection}

Deities such as the Charites, the Horai, and the Muses form close groups bound with complementary functions and family ties. Indeed, all are sisters: The Morai and the Horai are Themis' daughters, the Charites are Eurynome's daughters, and the Muses Mnemosyne's. To this are added Eilithyia and Hebe, daughters of Hera the wife of Zeus, who are shown grouped under the same mantle on Sophilos' dinos. ${ }^{45}$ By contrast, the association of Chariklo, Hestia, and Demeter, grouped under the same himation on the "François Vase", is less obvious. Chariklo is depicted on Sophilos' dinos paired with Leto and next to Demeter and Hestia. It is the same on the Acropolis

33 Paus. 9.25, 4 .

34 Paus. 9.35, 1-2. See: (Burkert 2011, p. 242, n. 576).

35 Paus. 2.20, 5; 5.15,3.

36 Hes. Theog. 1-75. On the cult of the Heliconian Muses: (Burkert 2011, p. 242, n. 575). See also, West commentary on Hesiod Theogony (1966), pp. 180-81.

37 Hes. Theog. 25, 29, 60, 76 .

38 Hes. Theog. 901-911. See (West 1966, pp. 405-08).

39 LSJ s.v. $\theta$ póvoc

40 Kleitarchos schol. Theoc. 2.59 (Scheid and Svenbro 1994, p. 63).

41 Hom. Od. 14. 486-502 (Eos); Hom. Il. 14. 154 (Hera); Aristoph. Birds, 904-905.

42 Pind. Pyth. 9.60; Nem. 3.83; Ol. 13.96.

43 Pind. Ol. 14.9-11. Note, also the special relationship to weaving since the Charites made Aphrodite's peplos (Hom. Il. 5.338).

44 See: Homeric Hymn to Aphrodite, 60-65, 84-90 (Aphrodite), 218 (Eos); Hom. Il. 14, 170-186 (Hera) who wear beautiful and

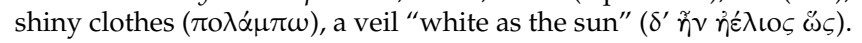

45 Hes. Theog. 921-923. 
fragment attributed to Sophilos that also represents Thetis and Peleus's wedding. ${ }^{46}$ Chariklo is the wife of the centaur Cheiron and the future foster mother of Achilles. ${ }^{47}$ Hestia and Demeter are sisters, daughters of Kronos, which could explain why Kleitias chose to pair them under the same mantle. Yet, their relationship to Chariklo remains an enigma (Gantz 1993, pp. 73-74, 145-46). ${ }^{48}$

The above observations reinforce my main hypothesis that the "shared-mantle" is an iconographical solution, which aims to picture the concept of unity in plurality, a community of persons united by special bonds, such as family ties. In the case of the "François vase", two pictorial solutions coexist to express the concept of unity in plurality for the painter. The first solution, by means of inscriptions, indicates the collective name of the deities in the plural, while representing them individually, for example, the Morai, or the Nymphai on Sophilos's dinos. The second solution uses the "shared-mantle" to indicate visually a group unity, while paired with the individual name of each deity. In the case where the shared mantle is paired with the name of deities in the plural, we see an overemphasis on the concept of unity, for example the Horai on the "François Vase" or the Muses and the Charites on Sophilos' dinos. All of these observations suggest that the concept of plurality is expressed by writing and/or painting, pairing "a concept and the visual transposition of this concept" (Halm-Tisserant 2005, pp. 41-42). But that does not explain why the Moirai depicted on the "François Vase" do not share a mantle, especially because they are sisters, united by complementary prerogatives; they are powers of distribution that monitor the major steps of life such as birth, wedding, and death (Pironti 2009; Pirenne-Delforge and Pironti 2011).

Based on the arguments mentioned above, we can say that the "shared-mantle" is a way to emphasize relationships between the characters that are mainly familial ties. This implies the idea of equality among the group members, whether the characters are individualized by their names or not. For example, the Muses on the "François Vase" are depicted next to each other forming a very homogeneous group. It is the same for the anonymous women on the Corinthian craters. On the crater in Basel, the figures form united groups that move in the same direction giving rhythm to the composition (Figure 7). This is also expressed in Hesiod's Theogony where the Muses are designated

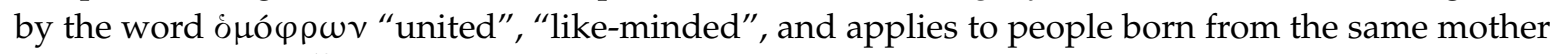
(West 1966, p. 176). ${ }^{49}$ The term also applies to people who share the same feelings, united by a common cause ${ }^{50}$ By contrast, the author of the Shield of Heracles highlights the paradox of Herakles and Iphicles,

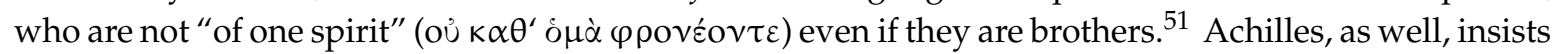
that he and Hector are enemies and cannot "have hearts of concord" ( like wolf and lamb. ${ }^{52}$

46 Fragment of a dinos attributed to Sophilos (ca. 580 BCE). Athens, National Museum Acropolis collection 1.587 (BAPD 305074, $A B V$ 39.15).

47 Pind. Pyth. 4, 103-105.

48 A solution to this odd association is, however, proposed by Torelli. For him, Chariklo is the nympheutria ("escort and prompter of the bride"), while Hestia and Demeter allude to the future of the bride. Hestia is depicted as the guardian of the hearth, Demeter as the protector of fecundity and other wealth and virtues of domestic life (Torelli 2013, pp. 92-93). The author does not mention that the three deities are assembled under the same himation, forming a group.

49 Hes. Theog. 60.

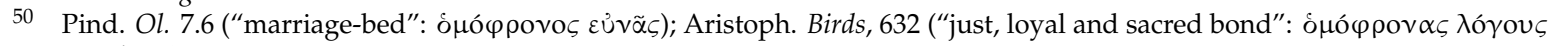

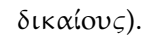

51 Ps-Hes. Shield, 49-50. See Chantraine DELG s.v. $\varphi \rho n ́ v$. On Heracles and Iphicles, twin brothers but physically very different: Attic red-figured stamnos attributed to the Berlin Painter (ca. 480-470 BCE), Paris, Louvre Museum G 192 (BAPD 201979; $A R V^{2}$. 208.160, 1633; Para. 343; Add². 195; LIMC I s.v. Alkeme 8; Dasen 1997, pp. 51-52).

52 Hom. Il. 22.263. 


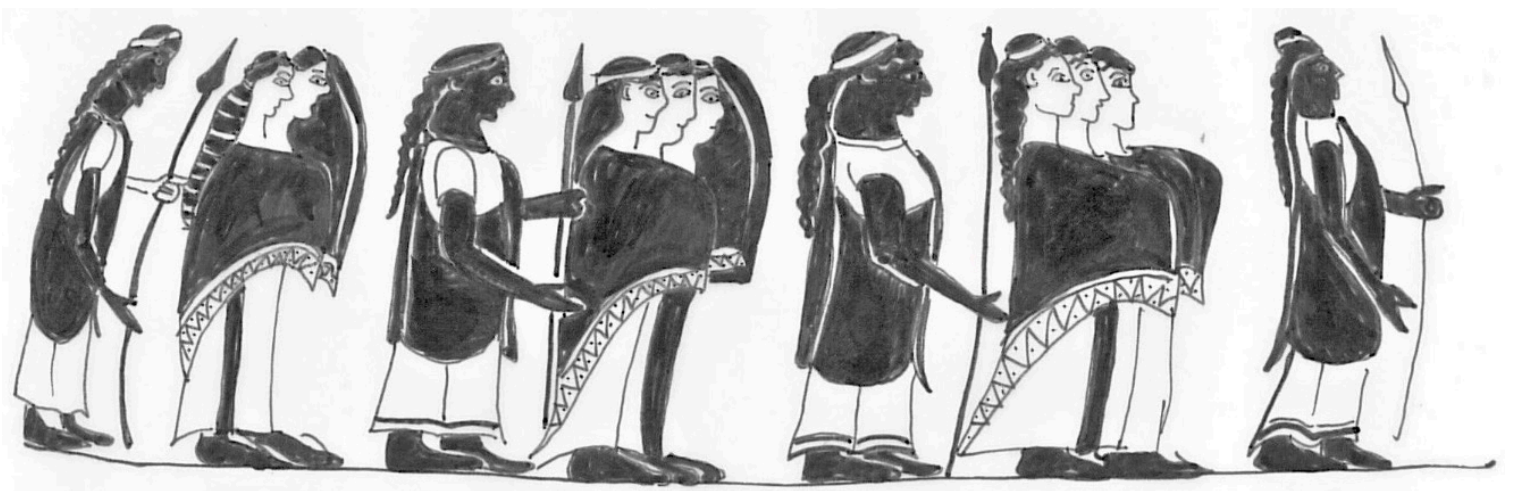

Figure 7. Corinthian column crater. Basel, Antikensammlung BS444. Maybe from Argos. Ca. 580-570 BCE. Drawing by the author.

\subsection{Choruses}

The Muses, as well as the Charites and the Horai, sing and dance, forming choruses in which they are equal as individuals, just as the word homophron suggests. This is confirmed by Calame's study on the choruses of young girls in archaic Greece (Calame 1977). Those choruses are characterized by friendship and camaraderie; the young girls are named hetairai (comrade, companion). ${ }^{53}$ They are of the same age and equal. The mythical choruses of Muses, Nereids, Charites, and Horai serve as a model for the human choruses. In Hesiod's Theogony, the Muses sing with "voices in tune" ( $\varphi \omega v \tilde{n}$ $\delta \mu \eta \rho \varepsilon \tilde{v} \sigma \alpha \mathrm{l})$, emphasizing the harmony that characterizes their songs. ${ }^{54}$ Choruses are also identified by family ties, such as the Muses, who are called "daughters of Zeus," as well as the Nymphai, who form choruses for Artemis, and the Nereids, called "Nereus' daughters" (Calame 1977, pp. 70-75). ${ }^{55}$ Likewise, as Calame notes, the young Argive girls in the service of Athena are called "Arestorides' daughters"; the maidens who dance and play the lyre for Artemis at Ephesus are named "Lydians" daughters" (Calame 1977, p. 72). More generally, choruses (male or female) form a united body of people of the same age and gender, singing and dancing together (Budelmann 2014, p. 91). This is precisely what the "shared-mantle" indicates visually, the unity and homogeneity of a group in which its members are equal.

We know that choral singing by young maidens and women occurred on occasions such as religious ceremonies or weddings (Calame 1977, pp. 148-52; Danielewicz 1990; Budelmann and Power 2015; Ladianou 2016, pp. 348-49). Choral singing was an important activity in ancient Greece, especially during marriage ceremonies when the hymeneal song was performed by several choruses (young girls, women, men). This is attested both by recent scholarship and ancient testimony (Calame 1977, pp. 159-62, 172-74; Oakley and Sinos 1993, pp. 26-27; Ladianou 2016, pp. 348-49). ${ }^{56}$ Songs and dances were accompanied by the syrinx, the aulos, and the cithara (Oakley and Sinos 1993, pp. 23-27). Also, in images, music instruments often indicate singing and/or dancing.

On a paradigmatic, mythological level, one of the Muses on Sophilos's dinos is depicted frontally playing the syrinx, flanked by two groups of pairs of Muses united by the same mantle and facing each other, forming a round dance (Figure 8). On the "François Vase," Kalliope is playing the syrinx leading two groups of Muses who follow Zeus and Hera on a chariot. What is more, on the Kypselos' chest as described by Pausanias, the inscription that accompanied the image specifies that the Muses are

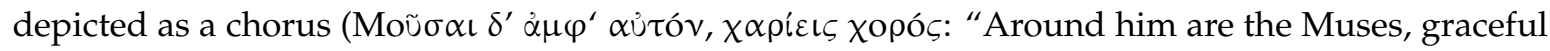

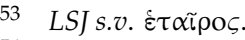

54 Hes. Theog. 39. See (West 1966, p. 170).

55 Hes. Theog. 25, 29, 60, 76; Plu. De def.orac. 11. 415 c,d; Bacch. 17. 102-103.

56 Sappho fr. 44 Voigt; Hom. Il. 18. 491-495. 
chorus"). ${ }^{57}$ Also, in Pindar and Euripides, the Muses, alongside the Horai and the Charites, sing at the wedding of Cadmus and Harmonia, and also at the wedding of Thetis and Peleus. ${ }^{58}$ Likewise, they are said to be homophron in Hesiod, a word that underlines their equal status as individuals among the group. As shown above, the Muses and the Nymphs are often depicted as overlapping groups in black-figure vase-painting, a visual solution that transcribed the idea of unity and homogeneity contained into the word homophron. These groups are interpreted as choruses accompanying Apollo such as on the hydria attributed to the Priam Painter mentioned earlier. ${ }^{59}$ On Sophilos' dinos and the "François Vase", it is in these instances that we find the choruses of the Horai, Charites, and Muses who sing at the wedding of Thetis and Peleus, thus ensuring the legitimacy of the event (Rudhardt 1999, pp. 82-96; Lissarrague 1999, pp. 14-15; Pironti 2009). This could also explain why the Morai do not share a mantle on the "François vase". They do not form a chorus, unlike the Horai or the Charites. But the goddesses are still a group, and their plurality is therefore indicated by their name in the plural.

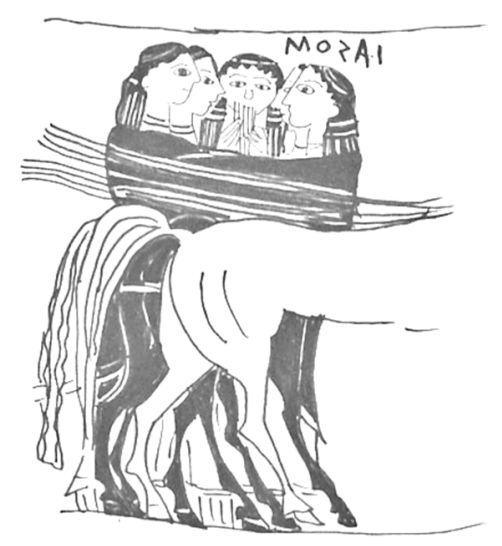

Figure 8. The Muses. Black-figured dinos (Attic). British Museum 1971, 1101.1. Signed by Sophilos. Ca. 580 BCE. Drawing by the author.

On the Corinthian depictions, the choruses remain anonymous; they take part in processions (maybe religious events) and weddings. Women who make up these groups are equal: They overlap and share the same piece of cloth, an effective visual indication of the unity and homogeneity of the group. In this regard, they are hetairai, in other words, comrade, companions, united for a common goal. In this context, the word hetairai, specific to the members of a chorus (Calame 1977), acts as a synonym for homophron that characterized the Muses. It underlines the unity of the group. The role of these anonymous mortal chorus is just as important as divine choruses. They assure the legitimacy of the event addressing their songs and dances to the gods (Oakley and Sinos 1993).

\section{Conclusions}

In conclusion, the close analysis of the "shared-mantle" motif consisting of three women standing together, slightly overlapping, and wrapped in the same cloak, points towards a symbolic meaning that has no parallel in real life. The "shared-mantle" is mostly used, as a pictorial solution that means group, solidarity, union, shared identity, and affection. As stated in the introduction, this does not mean that such an interpretation applies to all the depictions of the shared mantle. For example, pictures of two women facing each other under the same cloak have another meaning, probably ritual, as shown by Villanueva Puig (Villanueva Puig 2004). The "shared-mantle" is, above all, a means to

57 Paus. 5.18.4. See n. 18.

58 Pind. Pyth. 3.89-92; Eur. Iph. Aul. 1036-1047.

59 LIMC VI s.v. Mousa/Mousai 28a, b, 32, 33, 124, 126, 129a, 137 and commentary p. 673. Supra n. 21. 
depict unity in plurality. For this reason, it applies particularly well to plural deities such as the Muses, the Charites, the Horai, and the Morai. The motif allows the painter to underline, at the same time, the common identity of these deities as well as their family ties. Therefore, it seems not excessive to suggest that the "shared-mantle", in the form in which we studied it (three women walking together assembled by a common mantle), is also a way of depicting choruses.

Choruses are defined as "unison body" of people of the same age and the same gender. In vase-painting, the "shared-mantle" applies only to women whether they are anonymous or groups of deities. Moreover, the motif emphasizes the unity and homogeneity of the group. We observe that the "shared-mantle" motif appears only in processions, mostly wedding processions; and we know that music and singing were crucial in Ancient Greek weddings and religious celebrations. Choruses, depicted in the form of groups sharing the same himation, are a way to indicate, along with musical instruments, the sound environment of such events. Most of the vases that we commented are craters, used to mix wine and water during feast, sometimes wedding banquets ${ }^{60}$. Such images painted on craters could have had a special meaning to the feast participants or for the owner of the vase by reflecting, even if indirectly, on their own activity.

\section{Catalog}

The catalogue is established after (Buchholz 1987, pp. 26-33).

1. Corinthian column crater. Paris, Louvre Museum E634. From Caere. Ca. 600-590 BCE. Attributed to the Memnon Painter and the "Three maiden Group." Procession: Twice, two groups of three women assembled under the same mantle flanking a bearded man who holds a spear. Bibliography: (Buchholz 1987, No.40), with litt.

2. Corinthian column crater. Basel, Antikensammlung BS444. Maybe from Argos. Ca. 580-570 BCE. The "Three maiden Group", maybe Memnon Painter. Obverse: Two groups of three women grouped under the same mantle plus two women sharing the same mantle. The groups of women alternate with men holding a spear following a processional schema. Reverse: Horse riders. Bibliography: BAPD 1008775; CVA Basel 1, pl.12, n. 15. et pl. 13,6; (Buchholz 1987, No. 36 et No. 41 with litt).

3. Corinthian Column Crater. Vatican, Museo Gregoriano Etrusco 126 (16448). From Caere. Ca. 600-580 BCE. Wedding procession: Three groups of three women assembled under the same mantle. Wedded couple riding on a chariot, men with spears. BAPD 9019291. Bibliography: (Buchholz 1987, No. 42).

4. Corinthian column crater. Rome Villa Giulia Museum 46.197. From Cerveteri. Ca. 590-580 BCE. Three groups of three women assembled under the same mantle. Each group is facing a man riding on a chariot. Bibliography: (Amyx 1961, 11 n. 31; Gjodesen 1963, 338 n.28, Pl. 70 Figure 5).

5. Fragment(s) of a Corinthian column crater. The Hague, Scheurleer Museum 2032-2033. (with a fragment in Copenhagen, National Museum 12.350). From Rhodes. Early sixth century BCE. Three women under the same mantle facing a wedded couple riding on a chariot. Bibliography: CVA La Hague, Musée Scheurleer 2 III C 14, Pl. 8.3; (Benson 1969, Figure 14; Buchholz 1987, No. 44).

6. Fragment of a Corinthian column crater. The Hague, Scheurleer Museum. 2034. From Rhodes. Early sixth century BCE. Three women grouped under the same mantle. A man with a spear. Bibliography: CVA La Hague, Musée Scheurleer 2, III C 14, P1.8.4.

7. Black-figured pinax fragment (Corinthian). Athens National Museum. Maybe from Pitsa. Ca. 600-580 BCE. According to Orlandos: "the lower half of three figures covered by one and the

60 On the François vase as a wedding gift: Iozzo (2013) (Athenian context); Isler-Kerényi (1997) (Etruscan context). Corinthian craters: (Genière 1987, 1988). 
same garment, as on the François Vase". Bibliography: (Buchholz 1987, No. 43) (with litt.); (Orlandos 1935, p. 5; Jucker 1963, p. 56; Larson and Larson 2001, p. 261, Figure 5.18).

8. Black-figured cup (Attic). Berlin, Staatlische Museen F3993 (lost). From Argos. Early 6th century BCE. Obverse: Nine women grouped under the same mantle. The first, at right, is holding a wreath. In front of them is a young man. At the left: Two men. Reverse: Seven women grouped under the same mantle. BAPD 44223. Bibliography: (Furtwängler 1883, pl.51; Buchholz 1987, no. 50 with litt).

9. Black-figured dinos (Attic). London, British Museum 1971, 1101.1. Signed by Sophilos. Ca. 580 BCE. Maybe from Cerveteri, Etruria (Genière 1995, p. 39). BAPD 350099; Para. 16 bis; Add². 40.16 bis; (Buchholz 1987), No. 45.

10. Black-figured volute crater (Attic). Florence Museo Archeologico Etrusco inv. 4209. From Chiusi. Signed by Kleitias (painter) and Ergotimos (Potter). Ca. 570 BCE. BAPD 300000. ABV. 76.1, 682, Para. 29; $A d d^{2}$. 21Bibliography: (Buchholz 1987, No. 46; Shapiro et al. 2013).

11. Black-figured psykter (Chalcidian). Rome Coll. Castellani 47. From Caere. Ca. 540-530 BCE. Three women under the same mantle. Bibliography: (Buchholz 1987, No. 47 with litt).

12. Black-figured lidded amphora (Eretrian). Athens, National Museum 1004. Middle 6th century BCE. On the belly: wedding procession. Three women grouped under the same mantle followed by an aulos player and a wedded couple (deities or heroes) riding on a chariot. Following the chariot: Dionysos and Aphrodite (?). In the front of the procession: a torch bearer (Artemis?). Two small sirens fly below and before the horses. On the neck: Judgment of Paris. Reverse: Siren. Funerary amphora used to contain the remains of a child. Bibliography: (Collignon et al. 1902, pp. 200-02, n. 667; Boardman 1952, pp. 32-35, Pl. 9 a-b, Pl. 11a, 1998, p. 216, Figure 458.1).

Funding: This research received no external funding.

Acknowledgments: I am very grateful to C. Tanton and M.-C. Beaulieu for their careful proofreading and, of course, to the anonymous reviewers for their relevant and useful remarks that helped to significantly improve this paper.

Conflicts of Interest: The author declares no conflict of interest.

\section{References}

Amyx, Darrell Arllyn. 1961. The Medallion Painter. American Journal of Archaeology 65: 1-15. [CrossRef]

Cusset, Christophe, and Benjamin Acosta-Hugues. 2012. Euphorion, Oeuvres poétiques. Paris: Belles Lettres, n. 138. pp. 198-99.

Bettini, Maurizio, and Luigi Spina. 2010. Le Mythe Des Sirènes. Paris: Belin.

Benson, Jack L. 1969. The Three Maidens Group. American Journal of Archaeology 73: 109-22. [CrossRef]

Boardman, John. 1952. Pottery from Eretria. The Annual of the British School at Athens 47: 1-48. [CrossRef]

Boardman, John. 1998. Early Greek Vase Painting: 11th-6th Centuries BC: A Handbook. London: Thames and Hudson. Boardman, John. 2003. Athenian Black-Figure Vases. London: Thames \& Hudson.

Bodiou, Lydie, Dominique Frère, Véronique Mehl, and Alexandre Tourraix, eds. 2006. L'expression des Corps: Gestes, Attitudes, Regards dans l'iconographie Antique. Histoire, Cahiers d'histoire du corps antique; no. 2. Rennes: Presses Universitaires de Rennes.

Bonfante, Larissa. 1989. Nudity as a Costume in Classical Art. American Journal of Archaeology 93: 543-70. [CrossRef]

Buchholz, Hans-Günter. 1987. Das Symbol des gemeinsamen Mantels. Jahrbuch des Deutschen Archäologischen Instituts 102: 1-55.

Budelmann, Felix. 2014. Greek Festivals in and out of Context. In Choruses, Ancient and Modern. Edited by Joshua H. Billings, Felix Budelmann and Fiona Macintosh. Oxford: Oxford University Press, pp. 81-99.

Budelmann, Felix, and Timothy Power. 2015. Another Look at Female Choruses in Classical Athens. Classical Antiquity 34: 252-95. [CrossRef]

Burkert, Walter. 2011. La religion grecque: À l'époque archaïque et classique. Antiquité/Synthèses, 13. Paris: Picard. 
Cairns, Douglas L. 1996a. Off with Her AI $\Delta \Omega \Sigma^{\prime}$ : Herodotus 1.8.3-4. Classical Quarterly 46: 78-83. [CrossRef]

Cairns, Douglas L. 1996b. Veiling, Aí $\delta \dot{\omega} \varsigma$, and a Red-Figure Amphora by Phintias. The Journal of Hellenic Studies 116: 152-58. [CrossRef]

Cairns, DouglasL. 2002. The Meaning of the Veil in Ancient Greek Culture. In Women's Dress in the Ancient Greek World. Edited by Lloyd Llewellyn-Jones. London: Duckworth, Swansea: Classical Press of Wales, pp. 73-93.

Calame, Claude. 1977. Les chøurs de Jeunes Filles en Grèce Archä̈que. Filologia e critica; 20-21. Roma: Edizioni dell'Ateneo \& Bizzarri.

Cohen, Beth. 2001. Ethnic Identity in Democratic Athens and the Visual Vocabulary of Male Costume. In Ancient Perceptions of Greek Ethnicity. Edited by I. Malkin. Washington: Center of Hellenic Studies, Harvard University Press, pp. 235-74.

Collignon, Maxime, Louis Couve, and Georges Nicole. 1902. Catalogue des Vases Peints du Musée National d'Athènes. Paris: A. Fontenmoing, Available online: http://archive.org/details/cataloguedesvas00gregoog (accessed on 1 April 2019).

Crowhurst, Richard. 1963. Representations of Performance of Choral Lyric on the Greek Monuments, 800-350 B.C. Ph.D. Thesis, University of London, London, UK.

Danielewicz, Jerzy. 1990. Towards an Understanding of the Chorus: Homer on Early Forms of Lyric Poetry. Eos: Commentarii Societatis Philologae Polonorum 78: 55-62.

Dasen, Veronique. 1997. Multiple Births in Graeco-Roman Antiquity. Oxford Journal of Archaeology 16: 49-63. [CrossRef]

Deonna, W. 1914. Unité et Diversité. Revue Archéologique 23: 39-58.

Fridh-Haneson, Britt Marie. 1983. Le manteau symbolique: Étude sur les couples votifs en terre cuite assis sous un même manteau. Skrifter utgivna av Svenska institutet i Rom. $4^{\circ}$; 40. Stockholm: Svenska Institutet i Rom, Distributor PÅströms.

Furtwängler, Adolph. 1883. Die Sammlung Sabouroff. Berlin: Asher, Available online: http://digi.ub.uni-heidelberg. de/diglit/furtwaengler18831887bd1 (accessed on 29 March 2019).

Gantz, Timothy. 1993. Early Greek Myth: A Guide to Literary and Artistic Sources. Baltimore: Johns Hopkins University Press.

Genière, Juliette de la. 1987. Des usages du cratère. Revue des Études Anciennes 89: 271-82. [CrossRef]

Genière, Juliette de la. 1988. Les acheteurs des cratères corinthiens. Bulletin de Correspondance Hellénique 112: 83-90. [CrossRef]

Genière, Juliette de la. 1995. Quand Le Peintre Sophilos Signait Ses Oeuvres. Monuments et Mémoires de La Fondation Eugène Piot 74: 35-43. [CrossRef]

Gherchanoc, Florence, and Valérie Huet. 2007. Pratiques politiques et culturelles du vêtement. Revue historique 641: 3-30. [CrossRef]

Gherchanoc, Florence, and Valérie Huet. 2008. S'habiller, Se Déhabiller Dans Les Mondes Anciens. Mètis. Anthropologie Des Mondes Grecs Anciens 6. Paris-Athènes: Ehess-Deadalus.

Gjodesen, Mogens. 1963. Greek Bronzes: A Review Article. American Journal of Archaeology 67: 333-51. [CrossRef]

Guarducci, Margherita. 1928. Due o più donne sotto un solo manto in una serie di vasi greci arcaici. Mitteilungen des Deutschen Archäologischen Instituts, Athenische Abteilung LIII: 52-65.

Halm-Tisserant, Monique. 2005. Nommer Les Dieux Au Flanc Des Vases. In Nommer Les Dieux: Théonymes, Épithètes, Épiclèses Dans l'Antiquité. Edited by Nicole Brepols Belayche. Presses universitaires de Rennes, 41-51. Recherches Sur Les Rhétoriques Religieuses 5. Turnhout: Rennes.

Hésiode. 2008. Théogonie. Translated by Paul Mazon. Classiques En Poche 88. Paris: Les Belles Lettres.

Iozzo, Mario. 2013. The François Vase: Notes on Technical Aspects and Function. In The François Vase: New Perspectives. Edited by Harvey Alan Shapiro, Mario Iozzo and A. Lezzi-Hafter. Zürich: Akanthus, pp. 53-65.

Isler-Kerényi, Cornelia. 1997. Der François-Krater Zwischen Athen Und Chuisi. In Athenian Potters and Painters: The Conference Proceedings. Edited by John Howard Oakley, William D. E. Coulson and Olga Palagia. Oxford: Oxbow Monograph 67.

Jenkins, I. D. 1985. The Ambiguity of Greek Textiles. Arethusa 18: 109-32. Available online: https:/search.proquest. com/docview/1307036898/citation/DA5E1E2611848F2PQ/1 (accessed on 2 May 2019).

Johnston, Sarah Iles. 1999. Restless Dead: Encounters Between the Living and the Dead in Ancient Greece. Berkeley: University of California Press.

Jucker, Ines. 1963. Frauenfest in Korinth. Antike Kunst 6: 47-61. 
Jones, William Henry Samuel, and Ormerod, Henry Ardene. 1918. Description of Greece, Translated by Pausanias. 4 vols. Cambridge: Harvard University Press.

Karoglou, Kyriaki. 2010. Attic Pinakes: Votive Images in Clay. BAR. International Series 2104; Oxford: Archaeopress. Koch-Harnack, Gundel. 1989. Erotische Symbole: Lotosblüte und gemeinsamer Mantel auf Antiken Vasen. Berlin: Mann. Kurtz, Donna C., and John Boardman. 1971. Greek Burial Customs. Aspects of Greek and Roman Life. London: Thames and Hudson.

Ladianou, Katerina. 2016. Female Choruses and Garden of Nymphs: Visualizing Chorality in Sappho. In The Look of Lyric: Greek Song and the Visual. Studies in Archaic and Classical Greek Song. Edited by Vanessa Cazzato and André Lardinois. Leiden: Brill, vol. 1, pp. 343-69.

Larson, Jennifer, and Jennifer Lynn Larson. 2001. Greek Nymphs: Myth, Cult, Lore. Oxford: Oxford University Press.

Lee, Mireille M. 2012. Dress and Adornment in Archaic and Classical Greece. In A Companion to Women in the Ancient World. Edited by Sharon L. James and Sheila Dillon. Chichester and Malden: Wiley-Blackwell, pp. 179-90.

Lissarrague, François. 1990. L'autre Guerrier: Archers, Peltastes, Cavaliers dans l'imagerie Attique. Images à l'appui; 3. Paris: Découverte, Rome: École française de Rome.

Lissarrague, François. 1999. Vases Grecs: Les Athéniens et Leurs Images. Paris: F. Hazan.

Lissarrague, François. 2015. Ways of Looking at Greek Vases. In A Companion to Ancient Aesthetics. Edited by Pierre Destrée and Penelope Murray. Hoboken: John Wiley \& Sons, Inc., pp. 237-47. Available online: http://onlinelibrary.wiley.com/doi/10.1002/9781119009795.ch15/summary (accessed on 23 March 2016).

Llewellyn-Jones, Lloyd. 2003. Aphrodite's Tortoise: The Veiled Woman of Ancient Greece. Swansea: Classical Press of Wales, Oakville: Distributor in the United States, David Brown.

Murray, Penelope. 2008. Qu'est-Ce Qu'une Muse? Mètis. Anthropologie Des Mondes Grecs Anciens 6: 199-219.

Nagy, Gregory. 1999. The Best of the Achaeans: Concepts of the Hero in Archaic Greek Poetry. Baltimore: Johns Hopkins University Press.

Oakley, John Howard, and Rebecca H. Sinos. 1993. The Wedding in Ancient Athens. Madison: University of Wisconsin Press.

Orlandos, Anastasios. 1935. The Discovery of Painted Pinakes near Corinth. American Journal of Archaeology 39: 5. [CrossRef]

Paléothodoros, Dimitris. 2002. “Pourquoi Les Étrusques Achetaient-Ils Des Vases Attiques?". Les Études Classiques 70: 139-60.

Pipili, Maria. 2000. Wearing an Other Hat: Workmen in Town and Country. In Not the Classical Ideal: Athens and the Construction of the Other in Greek Art. Edited by Beth Cohen. Leiden: Brill, p. XVI. 559p.

Pirenne-Delforge, Vinciane, and Gabriella Pironti. 2011. Les Moires entre la naissance et la mort: De la représentation au culte. Études de lettres 3-4: 93-114. [CrossRef]

Pironti, Gabriella. 2009. Dans l'entourage de Thémis: Les Moires et Les 'Normes Parthénoniques'. In La Norme En Matière Religieuse En Grèce Ancienne: Actes Du XIe Colloque Du CIERGA (Rennes, Septembre 2007). Kernos Suppléments 21. Liège: Centre International d'étude de la Religion Grecque Antique, pp. 13-27.

Pironti, Gabriella. 2013. Entre ciel et guerre: Figures d'Aphrodite en Grèce ancienne. Kernos Suppléments. Liége: Presses Universitaires de Liège, Available online: http://books.openedition.org/pulg/236 (accessed on 11 July 2019).

Rabinowitz, Nancy Sorkin. 2002. Excavating Women's Homoeroticism in Ancient Greece: The Evidence from Attic Vase Painting. In Among Women: From the Homosocial to the Homoerotic in the Ancient World. Austin: University of Texas Press, pp. 106-66.

Reusser, Christoph. 2013. The François Vase in the Context of the Earliest Attic Imports to Etruria. In The François Vase: New Perspectives. Edited by Harvey Alan Shapiro, Mario Iozzo and Adrienne Lezzi-Hafter. Zürich: Akanthus, pp. 33-52.

Rodríguez-Pérez, Diana, ed. 2017. Greek Art in Context. Archaeological and Art Historical Perspectives. London and New York: Routledge.

Rudhardt, Jean. 1999. Thémis et les Hôrai: Recherche sur les divinités grecques de la justice et de la paix. Recherches et rencontres; 14 . Genève: Droz.

Scheid, John, and Jesper Svenbro. 1994. Le Métier de Zeus, Mythe Du Tissage et Du Tissu Dans Le Monde Gréco-Romain. Paris: La découverte. 
Shapiro, Harvey Alan., Mario Iozzo, and Adrienne Lezzi-Hafter. 2013. The François Vase: New Perspectives. Paper presented at the International Symposium, Villa Spelman, Florence, May 23-24; Kilchberg and Zürich: Akanthus Verl. für Archäologie.

Squire, Michael. 2015. Conceptualizing the (Visual) 'Arts'. In A Companion to Ancient Aesthetics. Edited by Pierre Destrée and Penelope Murray. Hoboken: John Wiley \& Sons, Inc., pp. 307-26. Available online: http://onlinelibrary.wiley.com/doi/10.1002/9781119009795.ch20/summary (accessed on 23 March 2016).

Steiner, Ann. 2007. Reading Greek Vases. New York: Cambridge University Press.

Stewart, Andrew F. 1997. Art, Desire, and the Body in Ancient Greece. Cambridge: Cambridge University Press.

Sutton, Robert F., Jr. 1981. The Interaction between Men and Women Potrayed on Attic Red-Figure Pottery. Ph.D. Dissertation, University of North Carolina, Chapel Hill, NC, USA.

Swift, Louise. 2016. Visual Imagery in Parthenaic Song. In The Look of Lyric: Greek Song and the Visual. Edited by Vanessa Cazzato and André Lardinois. Leiden: Brill, pp. 255-87.

Torelli, Mario. 2013. The Destiny of the Hero- toward a Structural Reading of the François Krater. In The François Vase: New Perspectives, Paper presented at the International Symposium Villa Spelman, Florence, Italy, May 23-24. Edited by Harvey Alan Shapiro, Mario Iozzo and Adrienne Lezzi-Hafter. Zurich: Akanthus, pp. 84-101.

Vermeule, Emily. 1979. Aspects of Death in Early Greek Art and Poetry. Berkeley: University of California Press.

Villanueva Puig, Marie-Christine. 2004. Deux Ménades Sous Le Même Manteau? Revue Des Études Anciennes 106: 445-54.

West, Martin L. 1966. Theogony, Translated by Hesiod. Oxford: Clarendon.

Williams, Dryfi. 1983. Sophilos in the British Museum. In Greek Vases in the J. Paul Getty Museum. Occasional Papers on Antiquity 1. Malibu: The J. Paul Getty Museum, pp. 9-34.

(C) 2019 by the author. Licensee MDPI, Basel, Switzerland. This article is an open access article distributed under the terms and conditions of the Creative Commons Attribution (CC BY) license (http://creativecommons.org/licenses/by/4.0/). 